\title{
Follicular thyroid carcinoma with pulsatile osseous metastases
}

\author{
Anil Bhansali, ${ }^{1}$ G Shanmugasundar, ${ }^{1}$ Rama Walia, ${ }^{1}$ Pinaki Dutta, ${ }^{1}$ Arvind Rajwanshi, ${ }^{2}$ Nalini Gupta ${ }^{2}$ \\ ${ }^{1}$ Endocrinology Department, PGIMER, Chandigarh, India; \\ 2Pathology Department, PGIMER, Chandigarh, India
}

Correspondence to Professor Anil Bhansali, anilbhansali_endocrine@rediffmail.com

\section{DESCRIPTION}

A 55-year-old woman, resident in an iodine-sufficient area, had a diffuse goitre for 25 years. She presented with a rapidly increasing swelling in the right frontal region for 3 months and increasing thyroid gland enlargement for 4 years. On examination, she had a diffuse, firm goitre (grade IV) with multiple tattoo marks and no cervical adenopathy. The swelling in the right frontal region $(6 \times 8 \times 6 \mathrm{~cm})$ was globular, firm, warm and pulsatile (figure 1); a similar swelling was present in the left shoulder region. On investigations, thyroid function tests and serum biochemistry were unremarkable. A lateral skull radiograph showed destruction of the frontal bone with an adjacent soft tissue mass. ${ }^{99 \mathrm{~m}} \mathrm{TcMDP}$ bone scan showed photopenic areas in skull, left shoulder, multiple vertebrae and the seventh rib (figure 1). FNAC from the thyroid gland and one of these scalp swellings was consistent with follicular carcinoma with metastases. She underwent total thyroidectomy uneventfully followed by ${ }^{131} \mathrm{I}$ ablation. Histopathology confirmed follicular thyroid carcinoma (figure 1). In endocrine practice, such visible osseous swellings over the skull are seen in malignancies with osseous metastasis and rarely in primary hyperparathyroidism involving skull bones due to osteitis fibrosa cystica. Usually these lesions are not pulsatile, however, high vascularity of metastatic lesions due to follicular thyroid carcinoma makes these lesions pulsatile. The reason for high vascularity of metastatic lesion with thyroid carcinoma is postulated as an increase in vascular endothelial growth factor (VEGF) or VEGF receptor expression by tumour tissue particularly in papillary and follicular thyroid carcinoma. ${ }^{1}$ The treatment for osseous metastases with thyroid carcinoma include ${ }^{131}$ I radioablation localised resection and sometimes radiotherapy. In our patient, these lesions are impressively decreased in size after ${ }^{131}$ I radioablation.

Competing interests None.

Patient consent Obtained.

\section{REFERENCES}

1. Vieira JM, Santos SC, Espadinha C, et al. Expression of vascular endothelial growth factor (VEGF) and its receptors in thyroid carcinomas of follicular origin: a potential autocrine loop. Eur J Endocrinol 2005;153:701-9.
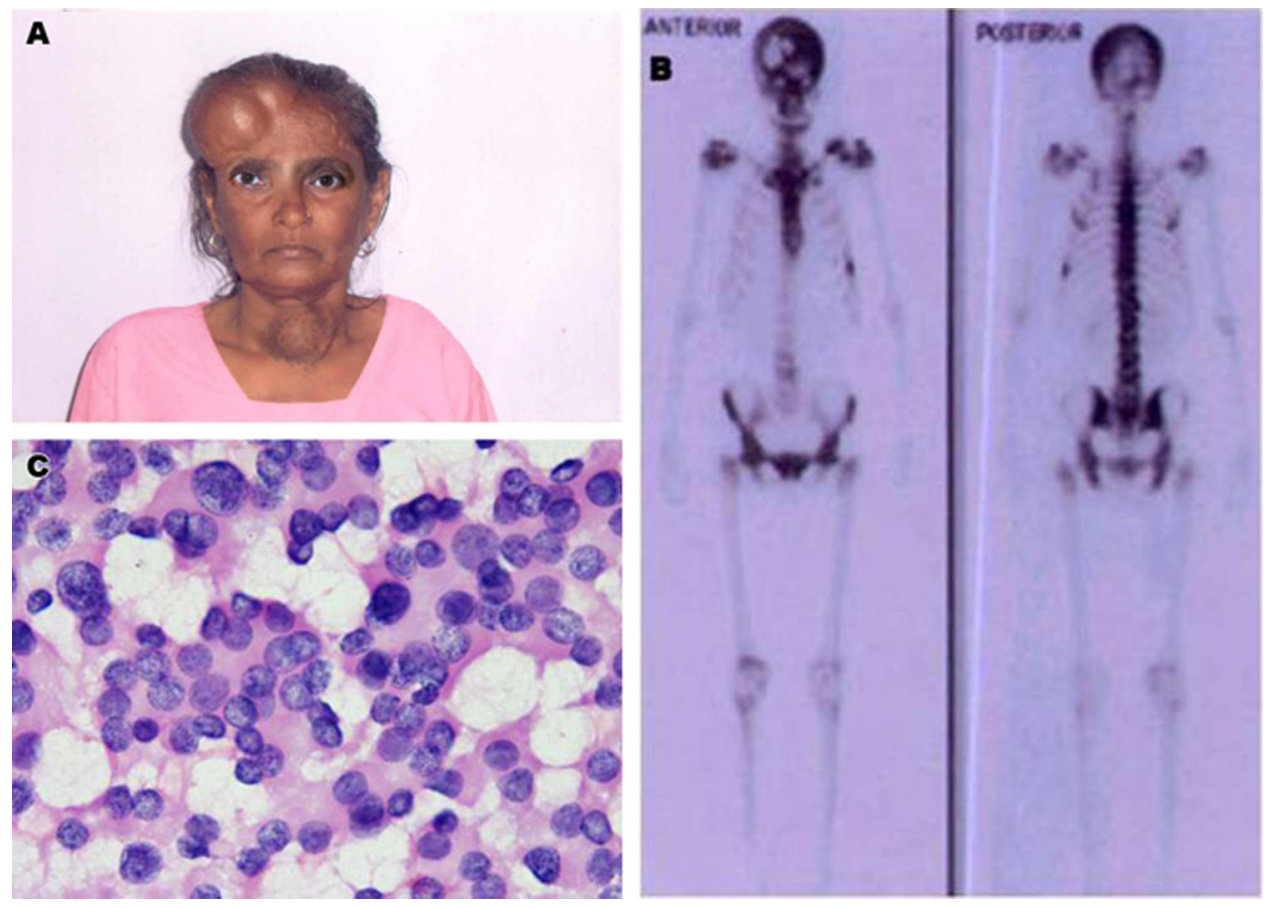

Figure 1 (A) Pulsatile swelling in right frontal region $(6 \times 8 \times 6 \mathrm{~cm})$. (B) ${ }^{99 \mathrm{~m} T c M D P}$ bone scan showed photopenic areas in skull, left shoulder, multiple vertebrae and the seventh rib. (C) Microphotographs showing cells with mild to moderate anisonucleosis and cell arrangement predominantly in microfollicular pattern (H\&E, 100x). 


\section{BMJ Case Reports}

This pdf has been created automatically from the final edited text and images.

Copyright 2012 BMJ Publishing Group. All rights reserved. For permission to reuse any of this content visit http://group.bmj.com/group/rights-licensing/permissions.

BMJ Case Report Fellows may re-use this article for personal use and teaching without any further permission.

Please cite this article as follows (you will need to access the article online to obtain the date of publication).

Bhansali A, Shanmugasundar G, Walia R, Dutv. Follicular thyroid carcinoma with pulsatile osseous metastases. BMJ Case Reports 2012; 10.1136/bcr.09.2010.3354, Published XXX

Become a Fellow of BMJ Case Reports today and you can:

- Submit as many cases as you like

- Enjoy fast sympathetic peer review and rapid publication of accepted articles

- Access all the published articles

- Re-use any of the published material for personal use and teaching without further permission

For information on Institutional Fellowships contact consortiasales@bmjgroup.com

Visit casereports.bmj.com for more articles like this and to become a Fellow 